\title{
Using Code-Switching as A Strategy for Improving Classroom Interaction at SMKN 1 Enrekang Regency
}

\section{Musdalifah}

English Education Department, Universitas Muhammadiyah Enrekang, Indonesia Jalan Jenderal Sudirman No. 17 Enrekang, Sulawesi Selatan 91712, Indonesia Email: musdalifah25okt@gmail.com

\section{ARTICLE INFO}

Article History:

Received 18 Januari 2019

Accepted 27 Januari 2020

\section{Keywords:}

Types of Code Switching, Functions of Code Switching, and factors cause the English teachers used code switching.

\begin{abstract}
The main objective of this research that was to known about what were types and the functions of code-switching used by English teachers, and what were factors cause the English teachers to use code-switching in classroom interaction at SMKN 1Enrekang regency. This research employed a descriptive qualitative design and purposive sampling technique. The participant of this research that was an English teacher at SMKN 1 Enrekang regency. The participant consisted of 3 English teachers who belong to three grades. There were some instruments were used to collect the data in this research namely observation, interview, questionnaire, and triangulation. The main findings of this research that was the English teachers of SMKN 1 Enrekang regency known types and functions of code-switching in classroom interaction, and know some factors cause they must to use code-switching in classroom interaction.
\end{abstract}

\section{INTRODUCTION}

Language has some functions for human in their life, one of function is can help to create an interaction in social life such as: in the office, in the market, in the school, in the hospital, etc. Indonesia language is national language for Indonesia country (Bloomfield, 2019) which is applied to communicate and interaction activities for different ethnics group in Indonesia country (Gumperz, 2019). Same with Indonesia language which has function as national language in Indonesia country
(Mustakim, 2019), English language is an international language which is used to communicate and interaction activities for all countries in the world. In Indonesia, English language is as foreign language, means that English is only teach and use in junior high schools, senior high schools, colleges, and in primary schools in four specific areas (Clyne, 2019).

One of the schools in Indonesia that is SMKN 1 Enrekang regency is facing many problems in teaching, learning, and interaction processes with use English language. The first problem comes from 
students; the students difficult to use the English language and motivation lack to practice it in their daily speaking. The last problem comes from English teachers of SMKN 1 Enrekang regency, their problems that are faced difficulties when they are doing teaching English language process.

Preparing to solve problems, the writer suggests changing the old teaching and learning techniques with the new technique that is code switching technique. Code switching is the selection by bilinguals or multilingual of forms from an embedded variety (or varieties) in utterances of a matrix variety during the same conversation (Modupeola, 2019), this means that code switching can be defined as the use of more than one language, variety, or style by a speaker within an utterance or discourse, or between different interlocutors or situations (Romaine, 2019). Code Switching was one of strategy that it could be chosen by teachers to be motivation tool for students when they were doing learning English language activity (Ruiz, 2019). Code switching was used by teachers during at learning and teaching English language especially in classroom interaction, this mean that teachers switch their languages from English languages to Indonesia languages or Indonesia languages to English languages and English languages to Mother Tongue or Mother Tongue to English languages (Mustakim (2019) \& (Khadidja, 2019). Sometimes teachers were not consciously to use code switching in their teaching English language process (Dagarin, 2020).

There are many types of code switching, Hoffman (2020) suggested that the types of the code switching as below: extra-sentential or tag switching, inter- sentential code switching, intra-sentential code switching. According Bloom (2020) there are four types forms in classroom interaction those are: situational code switching, metaphorical code switching, emblematic code switching, and establishing continuity with the previous speaker code switching. The last is Skiba (2019) concluded that there are three main types of code switching in linguistic skill and classroom interaction namely: referential code switching, directive code switching, and expressive code switching.

There are three experts are giving explanation about functions of code switching in classroom interaction, and all of them those are: the first expert is Yletyinen (2019), she summarized that the various functions of code switching as follows: to emphasize, to suit the domain of knowledge, to show Unequivalence, to reinforce a request, to clarify, and to communicate friendship or family bonding. The second expert is Jingxia (2020), she continued explanation from Yletyinen about function of code switching namely: to suit the language, to interject a conversation, to ease tension and inject humor into a conversation, to show a change of attitude and relationship, to exclude people from a conversation, and to talk certain topic. And the last expert is Uys (2019), He described that the functions of code switching as follows: lexical gap, repetition or reiteration, fixed vocabulary, translation, addressee specification, topic switch, affective function, and suiting language. The last explanation of this research that was factors cause the teachers used code switching in classroom interaction. Yletyinen (2019) suggested there were 2 main factors which were 
causing the teachers used code switching and all of them as follow: student lack of vocabularies, and to help the students understanding.

\section{METHOD}

\section{Design of Research}

This research applied descriptive qualitative design and purposive sampling technique. Descriptive qualitative design was one kind design of research which was used in the condition of natural setting (Sugiyono, 2019) and described about what types of code switching were used by the teacher in classroom interaction, what were the functions of code switching used by the teacher in classroom interaction and as well as the factors which caused teacher used code switching in classroom interaction. Purposive sampling technique was one of the techniques which were applied to determine the participants by using considering something (Sugiyono, 2019).

\section{Procedure of Collecting Data}

There were some steps that must be done as procedure of collecting data in this research, and all of them such as:

a. Recorded the utterances that produced by the teacher and students during six meetings of this research by using audio-recorder.

b. Made field notes relate to the teaching and learning activities in the classroom interaction.

c. Done interview section. The questions were direct for English teachers and focused for teachers' awareness in using code switching in language classroom, what were the functions of codes-switching, and what factors may cause the teachers use code-switching in classroom interaction.

d. Transcribed, identified, and classified the data then interpreted them. This research only analyzed the statement when the teachers used techniques of basic spoken questions.

\section{Procedure of Analyzing Data}

The ways was used to analysis data in this research that was discourse analysis. There were some steps which must be done for discourse analysis, and all of them as followed:

a. Collected issues or data by handphone and then transcribe the data.

b. Introduce the issues or data of power or roles in analysis data when necessary.

c. Described the interaction based on the recording.

d. Classified to find the types of code switching and the functions of code switching and also what factors may cause the teacher to use code switching in classroom interaction.

\section{RESULTS AND DISCUSSIONS}

\section{Types of Code Switching}

\section{a. Tag Switching}

Image 1. Extract of Code Switching with Type Tag Switching

$\mathrm{T} \quad$ : why did we write like this?, in Indonesia must to write "girl is beautiful yah". in English language we had a pattern okey. Di dalam bahasa Inggris kita memiliki rumusnya yah. The pattern is we should put adjective yah before noun, okey. (Why do we write like that, in Indonesia we should write "a girl is beautiful". In English language we had a pattern. The pattern is "we must put the adjective before noun)". 
Tag switching is type of code switching which involved a tag one language become an utterance. For example when the teachers explained about the material and then in the mild explanation the teachers insertion of tag in their utterance. Image 1 explained the teachers used code switching during classroom interaction. The teachers used tag switching when they explained the materials. For instance the teachers explained the materials they used tag such as "yah" and "okey" in their utterance. This switching involved the insertion of a tag, e.g. 'yah', 'okey' from language into a clause or sentence in a different language. The data also had shown from the observation if the teachers always used tag switching when they began to start the lesson, starting something new, checking progress, and also when the teacher gave the assignment.

\section{b. Intra-Sentential Switching}

Image 2. Extract of Code Switching with Type Intra-Sentential Switching

$\mathrm{T}$ : oke yah. Sekarang gini, after break. Setelah istirahat yah, you will bring product. You can buy from alfamart. (oke, now after breaking you must bring your product. You can buy it in alfamart)

$\mathrm{S}$ : APA sir? (Perdon sir?)

$\mathrm{T}$ : maksud saya setelah istrahat langsung beli product.( I mean, after breaking you must bring your product
Intra-sentential switching was code switching which occurred within a sentence. For example when the teachers explained the materials and they were switching their language from mother tongue language within a sentence. Image 2 explained the teachers often changed their speaking language from mother tongue language when getting down to star lesson, telling the objective materials, checking progress in running the class, gave them assignment and also making the announcement. This switching involved switches of different types occurring within the clause boundary, including within the word boundary, or translation of words or phrase substitution within a sentence. The teachers changed his language by saying "oke yah. sekarang gini, after break. Setelah istirahat yah, you will bring product. You can buy from alfamart". In utterance of teachers utterance there were so many codes switching that began from the first language to target language and the other way. They changed their language or phrase within a sentence.

\section{c. Inter-Sentential Switching}

Image 3. Extract of Code Switching with Type Inter-Sentential Switching

$T$ : good. Sebuah buku. As we know if singular there is word $a$, an. It is singular. Remember, if you find in english the word "a book" it means that singular. Tapi bukan itu saja yah, banyak yang lainnya. Singular has several meaning. Maksud saya a/an mempunyai makna yang berbedabeda,seperti sebuah, seekor..(good. A book. As we know that if a singular there is a article a/an. Remember, if you find in English the word "a book" it means singular. But, (but, not only that). Singular has several meaning. I mean article a/an has different meaning such as) 
Inter-sentential switching occurred between sentence and clause. In this case, one clause is in the one language, and the other to other language. Image 3 explained the teacher used intersentential switching during the classroom interaction. This switching involved a switch at clause/sentence boundary. In this case, one clause is in one language and the other in another language. Teachers changed their language when they explained the materials by saying "good. Sebuah buku. As we know, if singular there is word $a$, an. It was singular. Remember, if you find in English the word "a book" it means that singular. Tapi bukan itu saja yah, banyak yang lainnya. Singular has several meaning. Image 3 also explained teachers changed their language at clause and sentence level when he taught. Based on the extract, it was inter-sentential form because the teachers changed their language from mother tongue language became clause and sentence level. The last, image 3 occurred when the teachers checking register, getting down to start the lesson, starting something new, telling the objective materials, checking students understanding, checking progress, gave students assignment and when the teacher making announcement.

\section{Functions of Code Switching}

\section{a. Lexical Gap}

Image 4. Extract of Functions of Code Switching "Lexical Gap"
Image 4 showed the extract of functions of code switching "lexical gap". This image given two results, the first result was the background setting of extract, the background setting of extract that was this code switching was happening when the teachers explained the materials about describing things. Whilst the teachers taught, they did code switch from the target language to first language.

$\mathrm{T}$ : Okey, kalau thing, countable thing. Bukan thing pemikiran, tapi thing mati ng, think itu mati $K$ dia pemikiran. Jadi apa thing, thing. Benda-benda, benda-benda itu thing ya. Jadi, benda-benda yang dapat dihitung (follow together) jadi the thing and the count thing ya and then me something ya. Coba diliat dapat dihitung. Oke, sekarang. You have role the thing we something okey. What thing we can know? Benda apa yang ditau.(if. thing that has meaning "benda". So the countable noun it means the noun that we can be counted by role. Now, mentions what thing that vou know?)

The final result was image 4 presented many examples that the teachers changed their language because of their deficiency in target language (extract). For examples it occurred when the teachers taught by saying "kalau thing..., these extracts shown that the teachers changed their English language from mother tongue language because they felt more comfortable and easy to speak in their language.

\section{b. Repetition/Reiteration}


Image 5. Extract 1 and 2 of Functions of Code Switching "Repetition/Reiteration"

Image 5 showed the extract of functions of code switching "Repetition/Reiteration". This image given two results, the first result was the background setting of extract, the background setting of extract that was this code switching was happening when the teachers explained the materials. They changed their English language become mother tongue language in their teaching activity.

T: why we wrote same this?, In Indonesian must written these girl beautiful $y a_{,}$, , eee dear beautiful, in English language, we had specific formula okey. Dalam berbahasa inggris kita mempunyai spesifik rumusnya ya okey. The specific formula is we should put ya noun after adjective, okey. Where is adjective where is adjective of the sentence. Dimana adjective nya disitu?( why we were writing like this?. In English language, we write "the girl is beautiful yah". We role in English language. The specific formula that is we should adjective before noun. Where is adjective,,, where is

$T$ : the first that one, we must translate word by word ya. Kata demi kata dulu.( the first one, we must translate word by word).

$S \& T \quad:$ she is girl small beautiful.

The final result was image 5 explained in the extract 1 when the teachers said "..., in English we have a formula okey. Dalam Bahasa inggris kita punya rumusnya ya okey", they explained the materials by English and then they changed their language to first language for clarification the materials. Extract 2 showed that the teachers changed his language to emphasize the point in their utterance, such as "...we must translate word by word ya. Kata demi kata dulu...". Teachers did code switching in order to students know about the important point that the teachers meant.

\section{c. Fixed Vocabularies}

Image 6. Extract 1 and 2 of Functions of Code Switching "Fixed Vocabularies"
T : Yah bolla. She is a third grade student of senior high school in her hometown. Her age about seventeen.(she is a third grade student of senior high school in her hometown. Klo he itu laki laki klo she itu perem

S : Perempuaaaan!! ( female)

T : Okey, kalau thing, countable thing Bukan think pemikiran, tapi thing mati ng, think itu mati $K$ dia pemikiran. Jadi apa thing, things itu Benda-benda, benda-benda itu thing ya. Jadi, benda-benda yang dapat dihitung (follow together) jadi the thing and the count thing ya and then me something ya. Coba diliat dapat dihitung. Oke, sekarang. You have role the thing we something okey. What thing we can know? Benda apa yang ditau.( . (if thing, countable thing. Not think, but thing and the end $\mathrm{ng}$ (the end is $\mathrm{ng}$ ). thing that has meaning "benda". So the countable noun it means the noun that can be counted by role. Now, mentions 
Image 6 showed the extract of functions of code switching "fixed vocabularies". This image given two results, the first result was the background setting of extract, the background setting of extract that was the teachers changed their language when the teachers were explanation the materials and they found word and teachers intended to know about the word. The final result was image 6 explained in the extract 1 when they said "...Klo he itu laki laki klo she itu perem..." the teachers were referring to specific words he and she in order to students know about the meaning of words. In extract 2 also occurred when the teachers said"... maybe you can add, add itu tambah yah...". Here the teacher's specified utterances add, they changed their language to first language in order to students known about the word. It referred to words that were used routinely and only in one specific language to refer to school-related topics and items.

\section{Factors Cause Teachers Used Code Switching}

\section{a. Student Lack of Vocabularies}

The teachers used code switching because they thought that would be easy when they taught some materials and then by switching the language, it would be easier for students to get the point what was the point that the teachers wanted to deliver. In this case the data showed that what the teachers said when the writer was doing interview activity, and the teachers said:
“...Dengan pertimbangan bahwa ketika kita menjelaskan dengan bahasa inggris tetapi mereka tidak mengerti apa yang kita maksud. Otomatis kita harus mengalih bahasa supaya tujuan yang kita harapkan bias tercapai dan tersampaikan". By considering that when we explain materials by using English but the student can not understand it. Automatically, a teacher has to change his/her language to help them to understand the materials"(interviewed the subject).

From this interview process, the writer found that the teachers used code switching in speaking and interaction class because they thought that it was need to change the language into Indonesian because the students have lower capability and lack of vocabularies. Then, the teachers did code switching in classroom interaction because the students had lower capability in English. So, the teachers though need to change their language to make the students feel easier to understand.

\section{b. To Help the Students Understanding}

Second reason of teachers used code switching in classroom interaction because they perceived help the students understanding about the materials that the teachers explained. It could be seen on the following result of interview:

"Ketika seorang guru menjelaskan kepada siswa dan dia menjelaskannya dengan bahasa inggris tetapi anak-anak tidak tahu dalam memahami apa yang kita sampaikan, maka faktor nya adalah bahawa anak-anak merasa susah dalam memahami apa yang gurunya sampaikan dan tentunya sang guru harus membantu siswa agar apa yang ingin kita sampaikkan bias tersampaikan dengan 
baik dan siswa bias memahaminya dengan baik. When a teacher explained materials by using English, but the students did not understand it, the consequence is student found difficulty in comprehending materials. So teacher had to help them so they find it easily to understand what the materials is being explained".(interviewed the subject).

From this interview process, the writer found code switching which was applied by teachers in speaking and interaction classroom was helping the students understanding of materials.

In other words, when the teachers explained the materials and it indicated that the students did not understand about the materials. The teachers changed their language to help student were easy understand the materials.

\section{CONCLUSION and SUGGESTION}

Based on findings and discussion, the writer makes some conclusions. First, Code switching used by the teacher during the teaching and learning process consisted of three types; they are tag switching, intra-sentential code switching and inter-sentential code switching. These types not occurred in the same time whist teaching. Second, code switching has several functions; they are lexical gap, reiteration, fixed vocabulary, translation, addressee specification and affective function. And third, there are two main reasons why the teacher used code switching in the classroom interaction, and two of them namely: the first one is the students' lack of vocabularies and the second one is to help the students understand the materials.
Based on the conclusion, the writer give suggestions for teachers of SMKN 1 Enrekang regency to use code switching during the classroom interaction when the students have lower capability to make them easier in understanding the materials. Code switching also alternate language for the teachers when they teachers English language to make the students comfortable in English language.

\section{REFERENCES}

[1] Bloomfield. (2019). Language. Chicago: Holt Rinehart and Winston. 30-50.

[2] Bloom. (2020). Code-switching as a Strategy Use in an EFL Classroom Interaction. London: Penguin Book Ltd. 35-78.

[3] Clyne. (2019). Community languages and Classroom code switching of English language teachers at tertiary level. Melbourne: Cambridge University Press 40-61.

[4] Dagarin. (2020). Classroom interaction and communication strategies in learning English as a foreign language. Ljubljana: Slovene Association for the Study of English. 188-194.

[5] Gumperz. (2019). Discourse Strategies, the Development, and Use of Code-Switching among Simultaneous and Successive English Children. Melbourne: Cambridge University Press. 75-135.

[6] Hoffman. (2020). an Introduction to Bilingualism. New York: Longman. 80-155 
[7] Jingxia. (2020). Teachers codeswitching to the L1 in EFL classroom.

The Open Applied Linguistics Journal, 3, 10-23.

[8] Khadidja. (2019). The Effect of Classroom Interaction on Developing The Learners Speaking Skill. Department of Foreign Languages: Montour University-Constantine. 90-122.

[9] Modupeola. (2019). Code-Switching As a Teaching Strategy: Implication for English Language Teaching and Learning in a Multilingual Society. IOSR Journal of Humanities and Social Science, 14(3), 92-94.

[10] Puspawati, I. (2018). Teachers ' Use of Code Switching in EFL Classroom and its Functions. Journal of Foreign Language Teaching \& Learning, 3(1), 73-74.

[11] Mustakim, M., \& Samad, I. (2019). Essay Error Analysis on the 1st Year Students of English Education Department. MAJESTY JOURNAL, 1(2), 38-43. https://doi.org/10.33487/majesty.v $1 \mathrm{i} 2.121$

[12] Mustakim, M., \& Ismail, I. (2018). The Influence of English Camp in Improving Speaking Skill of English House Course Students in Maroangin Kabupaten Enrekang. Edumaspul: Jurnal Pendidikan, 2(2), 61-70.

https://doi.org/10.33487/edumaspu I.v2i2.10

[13] Romaine. (2019). Language in society. An introduction to sociolinguistics. Oxford: Oxford University Press. 178-210.

[14] Ruiz. (2019). Code switching: A tool in the classroom. (Published of Master Theses). State University of New York Collage, New York. Retrieved from: http://digitalcommons.brockport.ed u/cgi/.

[15] Skiba. (2019). Code Switching is Countenance of Language Interference. Internet TESL Journal. Vol. V. No: 05.

[16] Sugiyono. (2019). Metode penelitian pendidikan: Penelitian kuantitatif, kualitatif, dan $R$ \& $D$. Bandung: Alfabeta.135-137.

[17] Uys. (2019). The functions of teachers' code-switching in multilingual and multicultural high school classrooms. Stellenbosch: Stellenbosch University. 20-80.

[18] Yletyine. (2019). The functions of code switching in EFL classroom discourse. Jyvaskyla: University of Jyvaskyla. 35-90. 